\title{
BMJ Open Procalcitonin as a predictor of moderate to severe acute respiratory distress syndrome after cardiac surgery with cardiopulmonary bypass: a study protocol for a prospective cohort study
}

\author{
Han Chen, ${ }^{1}$ Zhang-Bo Cheng, ${ }^{2}$ Rong-Guo Yu ${ }^{1}$
}

To cite: Chen H, Cheng Z-B, Yu R-G. Procalcitonin as a predictor of moderate to severe acute respiratory distress syndrome after cardiac surgery with cardiopulmonary bypass: a study protocol for a prospective cohort study. BMJ Open 2014;4:e006344. doi:10.1136/bmjopen-2014006344

- Prepublication history for this paper is available online. To view these files please visit the journal online (http://dx.doi.org/10.1136/ bmjopen-2014-006344).

Received 9 August 2014 Revised 13 October 2014 Accepted 15 October 2014

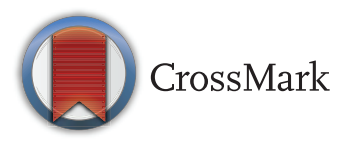

${ }^{1}$ Surgical Intensive Care Unit, Fujian Provincial Clinical College of Fujian Medical University, Fujian Provincial Hospital, Fuzhou, Fujian, People's Republic of China ${ }^{2}$ Department of Cardiosurgery, Fujian Provincial Clinical College of Fujian Medical University, Fujian Cardiovascular Research Institute, Fuzhou, Fujian, People's Republic of China

Correspondence to Professor Rong-Guo Yu; garyyrg@yahoo.com

\section{ABSTRACT}

Introduction: Procalcitonin (PCT) is activated during cardiopulmonary bypass (CPB) and may be a predictor of acute respiratory distress syndrome (ARDS). The objective of this study is to determine whether patients with different serum PCT concentrations exhibit different rates of developing moderate to severe ARDS. Methods and analysis: This is a prospective, single centre, observational cohort study. All patients admitted to the cardiosurgery department for cardiac surgery with CPB were screened for study eligibility. All eligible patients received a CPB procedure. Blood samples were obtained to determine white cell counts as well as $\mathrm{N}$-terminal pro-B-type natriuretic peptide, $\mathrm{C}$ reactive protein and PCT levels. Patients were assigned to the PCT elevated cohort or the control cohort based on serum PCT concentrations on the first postoperative day with a cut-off value of $7.0 \mathrm{ng} / \mathrm{mL}$. Data, including baseline, perioperative and outcome data, were collected daily for 7 days. The primary end point was the incidence of moderate to severe ARDS, which was diagnosed according to the Berlin definition.

Ethics and dissemination: The study was approved by the Institutional Review Board of Fujian Provincial Hospital. Study findings are disseminated through peerreviewed publications and conference presentations. Study registration: Chinese Clinical Trial Registry (ChiCTR-OCH-14005076).

\section{INTRODUCTION}

Epidemiological studies have demonstrated that cardiac surgery is a known risk factor for acute respiratory distress syndrome (ARDS). ${ }^{1-3}$ Over 300000 patients undergo cardiac surgery every year in the USA, and up to $20 \%$ will experience ARDS. ${ }^{4}$ The risk factors include the type of surgery, cardiopulmonary bypass, ischaemia-reperfusion injury, transfusion-related acute lung injury and drug toxicity. The mortality rate associated with ARDS is approximately $40 \%$ in the general population; however, this rate is considerably higher (up to $80 \%$ ) among postcardiac surgery patients. ${ }^{5} 6$ Moderate-to-severe ARDS causes the majority of deaths associated with this syndrome, and the possible therapeutic choices differ for the varying severities of ARDS. Patients with mild ARDS typically only require non-invasive treatments, whereas patients with moderate to severe ARDS are more likely to require more aggressive interventions, including prone positioning, recruitment manoeuvres, neuromuscular blockage agents, inhaled nitric oxide, high frequency oscillatory ventilation and even extracorporeal membrane oxygenation. Thus, the identification of patients with moderate to severe ARDS is clinically meaningful.

Although cardiac surgery with cardiopulmonary bypass (CPB) is considered a highly sterile type of surgery, it can lead to a systemic inflammatory response syndrome (SIRS). ${ }^{7}$ The possible causes of SIRS include the exposure of blood to non-physiological surfaces, ischaemia-reperfusion injury due to aortic clamping and extracorporeal circulation. $^{8}$ In addition, the translocation of gut endotoxins to the bloodstream after the release of the aortic clamp is another potential cause ${ }^{9}$ that can activate inflammatory cascades similar to those observed in sepsis. Cytokines, such as interleukin (IL)-6, IL-8, tumour necrosis factor- $\alpha$ and $\mathrm{G}$ reactive protein (CRP), lipoprotein-binding protein and procalcitonin (PCT) potentially play important roles in immune reactions, whereas PCT liberation is predominantly dependent on the use of CPB. ${ }^{10}$

PCT is initially described as an early, sensitive and specific marker for sepsis associated with bacterial infection. ${ }^{11}$ However, PCT 
levels are also increased in clinical situations not associated with infections, including major surgery, burns or trauma. ${ }^{12}$ Previous studies suggested that serum PCT concentrations increase at the end of CPB, peaking on the first day and then rapidly declining. ${ }^{7}{ }^{13}$ Data have suggested that significant increases in PCT levels are observed when complications present. ${ }^{714} 15$ Therefore, we hypothesise that PCT could serve as a predictor of the development of ARDS, especially moderate to severe ARDS, in patients undergoing cardiac surgery with CPB. Our aim is to determine whether patients with different serum PCT concentrations exhibit different rates of developing moderate to severe ARDS.

\section{METHODS AND ANALYSIS}

Study design overview

The present study is a prospective, single centre, observational cohort study involving patients undergoing elective cardiac surgery.

\section{Study setting and population}

The study setting is a cardiosurgical intensive care unit (ICU; 20 beds) and cardiosurgery department (118 beds) at Fujian Provincial Hospital (2500 beds), Fujian Provincial Clinical College of Fujian Medical University, Fuzhou, China.

All patients admitted to the cardiosurgery department for a cardiac surgery involving CPB were screened for study eligibility.

The following inclusion criteria were used:

1. Patients were 18 years of age and older;

2. Patients underwent cardiac surgery involving CPB;

3. Patients were free from active preoperative infection or inflammatory disease (all of the following criteria were achieved at study entry: leucocyte count $<12 \times 10^{9} / \mathrm{L}$, PCT $<0.5 \mathrm{ng} / \mathrm{mL}$, body temperature $<37.5^{\circ} \mathrm{C}$ );

4. Patients were capable of providing consent.

The following exclusion criteria were used:

1. History of chronic obstructive pulmonary disease (COPD), asthma or interstitial lung disease;

2. History of lung surgery;

3. Pregnant or lactating women;

4. Unwilling to provide consent;

5. Enrolled in another trial.

\section{Anaesthesia, CPB and perioperative management}

All patients undergo cardiosurgery with general anaesthesia via median sternotomy. Anticoagulation is promoted in CPB patients via the administration of $3 \mathrm{mg} / \mathrm{kg}$ sodium heparin. After attaining an activating clotting time (ACT) greater than $480 \mathrm{~s}$, CPB is initiated by using an occlusive roller pump (Jostra, Germany) and a membrane oxygenator (Affinity7000, American) followed by moderate hypothermia $\left(28^{\circ} \mathrm{C}\right)$ and crystalloid cardioplegic cardiac arrest. The pump flow is approximately $2.0-2.6 \mathrm{~L} / \mathrm{min} / \mathrm{m}^{2}$ during CPB. The mean arterial pressure is maintained at $60-80 \mathrm{~mm} \mathrm{Hg}$. At the end of surgery, protamine is administered at a 1:1 ratio to reverse the heparin effect (to obtain an ACT $<160 \mathrm{~s})$. The ventilator is initially set to deliver a tidal volume approximately $7-10 \mathrm{~mL} / \mathrm{kg}$, and the respiratory rate is adjusted to maintain an arterial $\mathrm{CO}_{2}$ pressure $\left(\mathrm{PaCO}_{2}\right)$ of $35-40 \mathrm{~mm} \mathrm{Hg}$ during the surgery. Cephazolin is administered as perioperative antibiotic prophylaxis. Patients are monitored postoperatively in the ICU and receive ventilation until the following criteria are met:

1. Awake and cooperative;

2. Adequate recovery of muscle strength;

3. Normal tidal volume, normocapnia (end-tidal carbon dioxide $30-45 \mathrm{~mm} \mathrm{Hg}$ ), and minimum pulse oxygen saturation $\left(\mathrm{SpO}_{2}\right) \geq 95 \%$ with a fraction of inspiration oxygen $\left(\mathrm{FiO}_{2}\right)$ of 0.5 ;

4. Haemodynamic stability (small dosage of vasopressor support and mean arterial pressure within $10-15 \%$ of baseline);

5. No severe arrhythmias;

6. No bleeding or indications of re-exploration.

The patient's endotracheal tube is removed if he/she achieves the criteria. Patients are discharged from the ICU after successful extubation. In our clinical practice, blood samples are routinely obtained for whole blood assessment prior to and 1 day after the operation. PCT is also assessed prior to and 1 day after the operation. $\mathrm{N}$-terminal pro-B-type natriuretic peptide (Nt-pro-BNP) and CRP levels are assessed 1 day after the operation. A chest X-ray is routinely obtained prior to the operation as well as 1 and 7 days after the operation. Additional chest X-ray examinations are performed if patients exhibit hypoxia due to suspicious infection, pulmonary atelectasis, pleural effusion or ARDS. A blood gas analysis is performed at least once daily when the patients are in the ICU. After they are transferred to a normal room, a blood gas analysis is performed when deemed necessary by the physicians or when patients' $\mathrm{SpO}_{2}$ cannot be maintained at a level greater than $95 \%$ with a $\mathrm{FiO}_{2}$ of 0.5 .

\section{Follow-up and data collection}

This is an observational study wherein no intervention is applied. At study entry, data regarding patient demographics, history of smoking, history of past illness patient characteristics, diagnosis and the New York Heart Association (NYHA) functional classification ${ }^{16}$ are collected. The type of surgery, duration of operation, CPB and aortic clamping, and net fluid balance during the operation are recorded. Serum CRP, Nt-pro-BNP and PCT concentrations are also recorded on the first postoperative day. Patients are assigned to the PCT elevated cohort or control cohort based on serum PCT concentrations on the first postoperative day using a cut-off value of $7.0 \mathrm{ng} / \mathrm{mL}$. Daily fluid balance and highest vasoactive-inotropic score (VIS) are calculated. VIS is calculated as dopamine dose $(\mu \mathrm{g} / \mathrm{kg} / \mathrm{min})+$ dobutamine 
Table 1 ARDS checklist

\begin{tabular}{|c|c|c|c|c|c|c|c|}
\hline & Day 1 & Day 2 & Day 3 & Day 4 & Day 5 & Day 6 & Day 7 \\
\hline $\begin{array}{l}\text { Timing: Within } 1 \text { week of a known clinical insult or } \\
\text { new or worsening respiratory symptoms }\end{array}$ & $\begin{array}{l}\text { Yes } \square \\
\text { No } \square\end{array}$ & $\begin{array}{l}\text { Yes } \square \\
\text { No } \square\end{array}$ & $\begin{array}{l}\text { Yes } \square \\
\text { No } \square\end{array}$ & $\begin{array}{l}\text { Yes } \square \\
\text { No } \square\end{array}$ & $\begin{array}{l}\text { Yes } \square \\
\text { No } \square\end{array}$ & $\begin{array}{l}\text { Yes } \square \\
\text { No } \square\end{array}$ & $\begin{array}{l}\text { Yes } \square \\
\text { No } \square\end{array}$ \\
\hline $\begin{array}{l}\text { new or worsening respiratory symptoms } \\
\text { Chest imaging: Bilateral opacities not fully }\end{array}$ & $\begin{array}{l}\text { No } \square \\
\text { Yes } \square\end{array}$ & $\begin{array}{l}\text { No } \square \\
\text { Yes } \square\end{array}$ & Yes $\square$ & Yes $\square$ & Yes $\square$ & Yes $\square$ & Yes $\square$ \\
\hline $\begin{array}{l}\text { explained by effusions, lobar/lung collapse or } \\
\text { nodules }\end{array}$ & No $\square$ & No $\square$ & No $\square$ & No $\square$ & No $\square$ & No $\square$ & No $\square$ \\
\hline $\begin{array}{l}\text { Origin of oedema: Respiratory failure not fully } \\
\text { explained by cardiac failure or fluid overload }\end{array}$ & $\begin{array}{l}\text { Yes } \square \\
\text { No } \square\end{array}$ & $\begin{array}{l}\text { Yes } \square \\
\text { No } \square\end{array}$ & $\begin{array}{l}\text { Yes } \square \\
\text { No } \square\end{array}$ & $\begin{array}{l}\text { Yes } \square \\
\text { No } \square\end{array}$ & $\begin{array}{l}\text { Yes } \square \\
\text { No } \square\end{array}$ & $\begin{array}{l}\text { Yes } \square \\
\text { No } \square\end{array}$ & $\begin{array}{l}\text { Yes } \square \\
\text { No } \square\end{array}$ \\
\hline \multicolumn{8}{|l|}{ Oxygenation } \\
\hline $\begin{array}{l}\text { Mild: } 200 \mathrm{~mm} \mathrm{Hg}<\mathrm{PaO}_{2} / \mathrm{FiO}_{2} \leq 300 \mathrm{~mm} \mathrm{Hg} \text { with } \\
\text { PEEP or CPAP } \geq 5 \mathrm{~cm} \mathrm{H}_{2} \mathrm{O}\end{array}$ & Yes $\square$ & Yes $\square$ & Yes $\square$ & Yes $\square$ & Yes $\square$ & Yes $\square$ & Yes $\square$ \\
\hline $\begin{array}{l}\text { Moderate: } 100 \mathrm{~mm} \mathrm{Hg}<\mathrm{PaO}_{2} / \mathrm{FiO}_{2} \leq 200 \mathrm{~mm} \mathrm{Hg} \\
\text { with PEEP } \geq 5 \mathrm{~cm} \mathrm{H}_{2} \mathrm{O}\end{array}$ & Yes $\square$ & Yes $\square$ & Yes $\square$ & Yes $\square$ & Yes $\square$ & Yes $\square$ & Yes $\square$ \\
\hline $\begin{array}{l}\text { Severe: } \mathrm{PaO}_{2} / \mathrm{FiO} 2 \leq 100 \mathrm{~mm} \mathrm{Hg} \text { with PEEP } \\
\geq 5 \mathrm{~cm} \mathrm{H}_{2} \mathrm{O}\end{array}$ & Yes $\square$ & Yes $\square$ & Yes $\square$ & Yes $\square$ & Yes $\square$ & Yes $\square$ & Yes $\square$ \\
\hline Has the patient developed ARDS? & $\begin{array}{l}\text { Yes } \square \\
\text { No } \square\end{array}$ & $\begin{array}{l}\text { Yes } \square \\
\text { No } \square\end{array}$ & $\begin{array}{l}\text { Yes } \square \\
\text { No } \square\end{array}$ & $\begin{array}{l}\text { Yes } \square \\
\text { No } \square\end{array}$ & $\begin{array}{l}\text { Yes } \square \\
\text { No } \square\end{array}$ & $\begin{array}{l}\text { Yes } \square \\
\text { No } \square\end{array}$ & $\begin{array}{l}\text { Yes } \square \\
\text { No } \square\end{array}$ \\
\hline
\end{tabular}

dose $(\mu \mathrm{g} / \mathrm{kg} / \mathrm{min})+100 \times$ epinephrine dose $(\mu \mathrm{g} / \mathrm{kg} / \mathrm{min})$ $+100 \times$ norepinephrine dose $(\mu \mathrm{g} / \mathrm{kg} / \mathrm{min})+15 \times$ milrinone dose $(\mu \mathrm{g} / \mathrm{kg} / \mathrm{min})+10000 \times$ vasopressin dose $(\mathrm{U} / \mathrm{kg} /$ min). ${ }^{17}$ Data are collected until the seventh day after the operation. ARDS is diagnosed according to the Berlin definition. ${ }^{18}$ A checklist (table 1) is used to assess the development of moderate to severe ARDS. Two physicians make the diagnosis independently. Only patients diagnosed with moderate to severe ARDS by both physicians are considered. Echocardiography or pulmonary artery catheter (PAC) is applied to exclude hydrostatic oedema. Physicians who assess the development of ARDS are unaware of the patient's PCT level.

\section{PCT determination}

Serum PCT levels were measured using a highly sensitive and specific commercially available immunoluminometric assay kit (Vidasbrahms PCT, mini VIDS, Italy) according to the manufacturer's recommendation. Quantitative measurement allowed the determination of PCT concentrations ranging from 0.05 to $200 \mathrm{ng} / \mathrm{mL}$.

\section{Study end points}

The primary end point is the incidence of moderate to severe ARDS.

The secondary end points include the following:

1. The duration of mechanical ventilation;

2. The length of ICU stay;

3. Complications after surgery.

\section{Sample size}

Primarily, we expect the incidence of moderate to severe ARDS to be increased in the PCT elevated group compared with the control group. Previous investigations indicate the overall morbidity of moderate to severe ARDS was approximately $0.5-2 \%$ of patients undergoing cardiac surgery. ${ }^{1-3}$ Our pilot study revealed that the incidence could be as high as $15 \%$ in patients with elevated PCT levels. Using the Power and Sample Size Calculation program, 64 exposure participants and 64 control participants must be investigated to be able to reject the null hypothesis. The type I error probability $(\alpha)$ for testing our null hypothesis is 0.05 , and the type II error probability $(\beta)$ is 0.2 .

\section{Statistical analysis}

Baseline characteristics were summarised using univariate analyses. Categorical variables are presented as numbers and percentages, and analysed using the $\chi^{2}$ test. Continuous variables are assessed for normal distribution and presented as means and SDs or medians and IQR as appropriate. Continuous variables are compared using the Student's t test for normally distributed variables and the Mann-Whitney $U$ test for non-normally distributed variables. All tests of significance were two sided and conducted at the 5\% significance level. Subgroup analysis was performed to illustrate the effects of different types of surgery. Analyses are performed using SPSS 19.0 (IBM Corporation, New York, USA).

\section{Ethical aspects and informed consent}

The study protocol and consent forms were approved on 7 August 2014 by the Institutional Review Board of Fujian Provincial Hospital. The study was registered on 8 August 2014 at ClinicalTrials.org (ChiCTR-OCH14005076).

After patient eligibility for the study is confirmed, the study coordinator is introduced to the family. The surgeon ensures that the family is aware of the study coordinator's credentials and indicates that this individual will discuss the research programme being 
conducted and that the patient is qualified to participate. Every relevant aspect of the project is described. The study coordinator frequently pauses to ask if there are any questions and requests that the family repeat the topic being discussed in their own words to ensure that they understand. The study coordinator is especially careful to assure the family that they are free to decline consent without consequences and that they can withdraw consent at any time without impacting treatment. Family members are provided contact information for the study coordinator, local coinvestigator and the local Ethical Committee. Written consent is obtained in the presence of a witness.

\section{Dissemination plan}

The study results will be submitted to an international peer reviewed journal. Results will also be presented at national and international conferences relevant to the subject fields. We will also consider disseminating the results to the participants.

Contributors $\mathrm{HC}$ and R-GY participated in the study design and drafted the manuscript. Z-BC participated in the study design. All authors edited the manuscript, read and approved the final manuscript.

Funding This work was supported by grants from the National Clinical Key Specialty (2011170)..

Competing interests None.

Ethics approval The study was approved by the Institutional Review Board of Fujian Provincial Hospital.

Provenance and peer review Not commissioned; externally peer reviewed.

Open Access This is an Open Access article distributed in accordance with the Creative Commons Attribution Non Commercial (CC BY-NC 4.0) license, which permits others to distribute, remix, adapt, build upon this work noncommercially, and license their derivative works on different terms, provided the original work is properly cited and the use is non-commercial. See: http:// creativecommons.org/licenses/by-nc/4.0/

\section{REFERENCES}

1. Milot J, Perron J, Lacasse $Y$, et al. Incidence and predictors of ARDS after cardiac surgery. Chest 2001;119:884-8.

2. Christenson JT, Aeberhard JM, Badel P, et al. Adult respiratory distress syndrome after cardiac surgery. Cardiovasc Surg 1996;4:15-21.

3. Kaul TK, Fields BL, Riggins LS, et al. Adult respiratory distress syndrome following cardiopulmonary bypass: incidence, prophylaxis and management. J Cardiovasc Surg 1998;39:777-81.

4. Stephens RS, Shah AS, Whitman GJ. Lung injury and acute respiratory distress syndrome after cardiac surgery. Ann Thorac Surg 2013:95:1122-9.

5. Weissman C. Pulmonary complications after cardiac surgery. Semin Cardiothorac Vasc Anesth 2004;8:185-211.

6. Rubenfeld GD, Caldwell E, Peabody E, et al. Incidence and outcomes of acute lung injury. N Engl J Med 2005;353:1685-93.

7. Prat $C$, Ricart $P$, Ruyra $X$, et al. Serum concentrations of procalcitonin after cardiac surgery. J Card Surg 2008;23:627-32.

8. Hennein HA, Ebba $\mathrm{H}$, Rodriguez $\mathrm{JL}$, et al. Relationship of the proinflammatory cytokines to myocardial ischemia and dysfunction after uncomplicated coronary revascularization. J Thorac Cardiovasc Surg 1994;108:626-35.

9. Rocke DA, Gaffin SL, Wells MT, et al. Endotoxemia associated with cardiopulmonary bypass. J Thorac Cardiovasc Surg 1987;93:832-7.

10. Franke A, Lante W, Fackeldey V, et al. Pro-inflammatory cytokines after different kinds of cardio-thoracic surgical procedures: is what we see what we know? Eur J Cardiothorac Surg 2005;28:569-75.

11. Assicot M, Bohuon C, Gendrel D, et al. High serum procalcitonin concentrations in patients with sepsis and infection. Lancet 1993;341:515-18.

12. Reinhart K, Karzai W, Meisner M. Procalcitonin as a marker of the systemic inflammatory response to infection. Intensive Care Med 2000;26:1193-200.

13. Kallel S, Abid M, Jarraya A, et al. [Kinetics, diagnostic and prognostic value of procalcitonin after cardiac surgery]. Ann Biol Clin (Paris) 2012;70:567-80.

14. Dorge $\mathrm{H}$, Schondube FA, Dorge $\mathrm{P}$, et al. Procalcitonin is a valuable prognostic marker in cardiac surgery but not specific for infection. Thorac Cardiovasc Surg 2003;51:322-6.

15. Kallel S, Jmel W, Jarraya A, et al. The role of procalcitonin and $\mathrm{N}$-terminal pro-B-type natriuretic peptide in predicting outcome after cardiac surgery. Perfusion 2012;27:504-11.

16. AHA medical/scientific statement. 1994 revisions to classification of functional capacity and objective assessment of patients with diseases of the heart. Circulation 1994;90:644-5.

17. Gaies MG, Gurney JG, Yen AH, et al. Vasoactive-inotropic score as a predictor of morbidity and mortality in infants after cardiopulmonary bypass. Pediatr Crit Care Med 2010;11:234-8.

18. Ranieri VM, Rubenfeld GD, Thompson BT, et al. ARDS Definition Task Force. Acute respiratory distress syndrome: the Berlin Definition. JAMA 2012;307:2526-33. 